\title{
https://doi.org/10.46813/2021-134-183 \\ IMPACT OF CORONA DISCHARGE ON SERRATIA MARCESCENS AND PSEUDOMONAS SYRINGAE INACTIVATION
}

\author{
O.A. Nedybaliuk, N.S. Kot, A.V. Kharina, I.I. Fedirchyk \\ Taras Shevchenko National University of Kyiv, Kyiv, Ukraine \\ E-mail: oanedybaliuk@gmail.com
}

This work investigates the influence of corona discharge working in different treatment modes on the Serratia marcescens and Pseudomonas syringae bacteria cultures. The current-voltage characteristics of the discharge were measured in the $4 \ldots .50 \mu \mathrm{A}$ current range. The typical current and voltage oscillograms of corona discharge were measured when the pin's point was near the water surface. Several treatment modes were discovered, which allowed to destroy or decrease the quantity of Serratia marcescens and Pseudomonas syringae bacteria by several orders of magnitude using $0.3 \mathrm{~W}$ corona discharge. The absorption spectra of the distilled water treated by the corona discharge were measured.

PACS: 52.80.Hc, 52.50.Dg

\section{INTRODUCTION}

The spread of drug-resistant bacterial infections, which make antibiotics ineffective, pushes medical science to look for additional therapeutic options that allow treatment of the different types of infections.

As time goes on, the use of atmospheric pressure plasma for solving biomedical problems becomes increasingly more popular. Plasma-based disinfection became a popular alternative to technical sterilization due to its low cost and high efficiency comparing to other methods.

The use of low-temperature atmospheric pressure dielectric barrier discharge plasma for the sterilization of bacteria was studied in [1]. In addition, the bactericidal properties of plasma jets produced by the lowcurrent spark discharges and their influence on $E$. coli strains were investigated [1]. The time of treatment by the low-current spark discharge was ranging from 5 to $60 \mathrm{~s}$. The distance between a plasma source and bacterial growth surface was between 5 and $30 \mathrm{~mm}$ [1].

The inactivation of live cells after the short treatment by the ultra low frequency plasma using a radiofrequency source was investigated in work [2]. Work [2] aimed at the inactivation of the $E$. coli with and without the presence of a magnetic field. The addition of oxygen and argon into discharge led to the complete inactivation of the bacteria. The speed of inactivation was increasing with the rise of oxygen concentration. Work [2] concludes that the survival curve is influenced by many parameters. The inactivated area was significantly larger when the oxygen was added to argon using $\mathrm{Ar} / 3 \% \quad \mathrm{O}_{2}$ mixture, especially in the case of longer treatments. In addition, higher oxygen concentration improved the bacterial inactivation ability of the lowpressure plasma. The presence of a magnetic field has been shown to increase the plasma density over the sample, which increases the sharp inhibition of the residual survival by the plasma discharge.

Work [3] presented the results of plasma sterilization of the samples of two etalon bacterial strains Pseudomonas aeruginosa ATCC 27853 and Enterococcus faecalis ATCC 29212. The power of the plasma-generating discharge was shown to be less than $2 \mathrm{~W}$, it produced basic oxygen and nitrogen radicals, which are responsi- ble for sterilization. All cases have shown the decrease of the bacteria concentration by several orders of magnitude and destruction of the bacteria with the longest time of treatment.

The authors of work [4] used the atmospheric pressure air plasma produced by a surface barrier discharge as an innovative method of fungi inactivation, which can efficiently replace common chemical disinfection. The tests were conducted using both a direct air plasma treatment and an indirect treatment via plasma-activated water solution. The concentrations of the gaseous ozone and nitrogen oxides were measured using Fouriertransform infrared spectroscopy and optical emission spectroscopy. The direct plasma treatment has shown higher efficiency of disinfection and spore destruction. Moreover, an investigation on the production of a wide range of active oxygen and nitrogen species was conducted [4].

Work [5] provides preliminary experimental studies of the efficiency of a plasma jet on non-active bacteria. In this study, E. coli was treated by a plasma produced from two different gas mixtures (helium and helium mixed with $0.75 \%$ oxygen) for either 30 or $120 \mathrm{~s}$. The inactivated area increased with the rise of the time of the plasma discharge treatment and became significantly larger with the addition of oxygen to helium, especially for the longer treatment time [5].

Analysis of works [1 - 5] shows that studied samples are significantly affected after being treated using lowpower plasma discharge. It was determined that the increase of treatment time allows for effective inactivation of a much larger area.

In previous research, we studied the influence of the corona discharge on the germination of spores and the development of higher fungi mycelium [6]. Depending on the treatment mode, the corona discharge was able to either speed up or slow down the growth of the higher fungi mycelium [6]. Works [7, 8] have also shown that plasma influences the surface tension of liquids.

This work studies the impact of corona discharge on the infectious properties of bacteria using Serratia marcescens and Pseudomonas syringae bacteria cultures as samples. 


\section{EXPERIMENTAL SET-UP AND METHODOLOGY}

The influence of corona discharge on the inactivation of Serratia marcescens and Pseudomonas syringae bacteria was studied using an experimental setup with a pin-to-ring electrode configuration (Fig. 1).

The internal diameter of the ring was $12 \mathrm{~mm}$ and the diameter of the pin was $0.15 \mathrm{~mm}$. The power source could supply discharge with a voltage between 0 and $7 \mathrm{kV}$. The pin was made of tungsten and used as a highvoltage cathode. The ring was made of stainless steel and used as a grounded anode. The voltage was measured using a voltage divider consisting of $1.6 \mathrm{G} \Omega$ resistance $R_{1}$ and $1.5 \mathrm{k} \Omega$ resistance $R_{2}$.

The studies were conducted on the Serratia marcescens and Pseudomonas syringae bacterial cultures provided by the Laboratory of Microbial Ecology of the Institute of Molecular Biology and Genetics of the National Academy of Sciences of Ukraine.

Serratia marcescens is a species of gram-negative bacteria in the family Yersiniaceae. It is an opportunistic pathogen bacteria that can cause infections in several sites of the human body. It is a motile bacteria that grows in a wet environment at temperatures between 5 and $40^{\circ} \mathrm{C}$ and $\mathrm{pH}$ between 5 and 9 . It is a facultative anaerobe. During its life, it produces a red pigment called prodigiosin.

Pseudomonas syringae is a rod-shaped gramnegative plant pathogen bacterium with polar flagella. It causes many plant diseases, including stem cankers, necrotic leaf spots, and spots and blisters on fruit. Pseudomonas syringae has approximately 50 strains that can infect a large number of different plant species.

The cultures were germinated in the Petri dish at sterile conditions. $1.4 \%$ agar was poured into a Petri dish and given time to congeal. The inoculation loop was used to spread the bacterial cultures over the Petri dish with the optimal treatment radius. The Petri dish was left for $30 \mathrm{~min}$ at room temperature to assure the diffusion of bacteria into the agar. All manipulations were done in sterile conditions to prevent contamination by the outside microflora. Several different treatment times were used for corona discharge treatment of samples: $2.5,5,7.5,10,15$, and $20 \mathrm{~min}$.

\section{RESULTS AND DISCUSSION}

The current-voltage characteristics of the corona discharge were measured (Fig. 2) when the point of the pin electrode (see Fig. 1, (6)) was located in the plane of the ring electrode (see Fig. 1, (5)). The breakdown voltage of corona discharge was determined to be $(2.7 \pm 0.1) \mathrm{kV}$. Fig. 3 shows the dependence of the average power of corona discharge on the discharge current.

Figs. 4 and 5 show the typical current and voltage oscillograms of the corona discharge burning in the air (see Fig. 4) and burning at the $5 \mathrm{~mm}$ distance between the point of a pin electrode and the surface of the distilled water (see Fig. 5).

The experiments were conducted in two stages. During the first stage, we selected a wide range of operating modes while trying to find the optimal conditions for the treatment of Serratia marcescens. The treatment modes of Serratia marcescens bacteria are shown in Table 1. Fig. 6 shows the photos of the control sample and the Serratia marcescens samples treated using corona discharge.

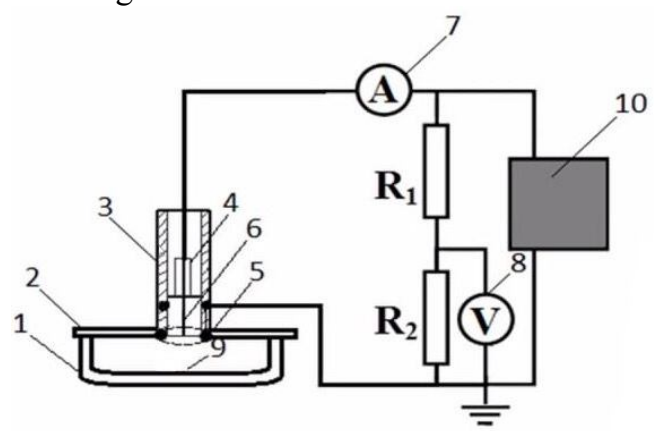

Fig. 1. Experiment diagram: 1 - Petri dish; 2 -cover; 3, 4 -insulator; 5 - metal ring; 6 -tungsten pin; 7 -ammeter; 8 -voltmeter; 9 -studied sample; 10 - power source

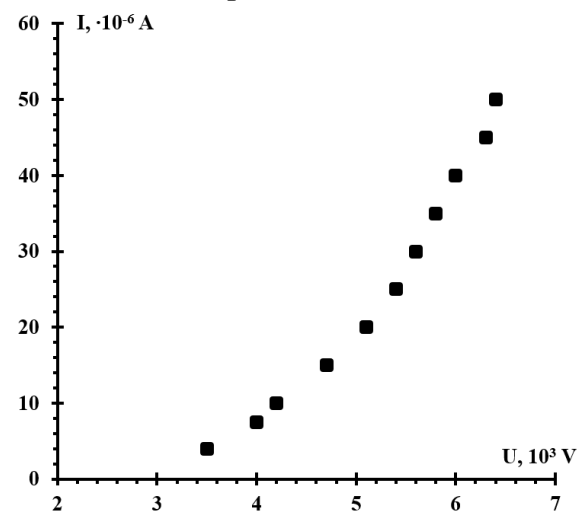

Fig. 2. Current-voltage characteristic of corona

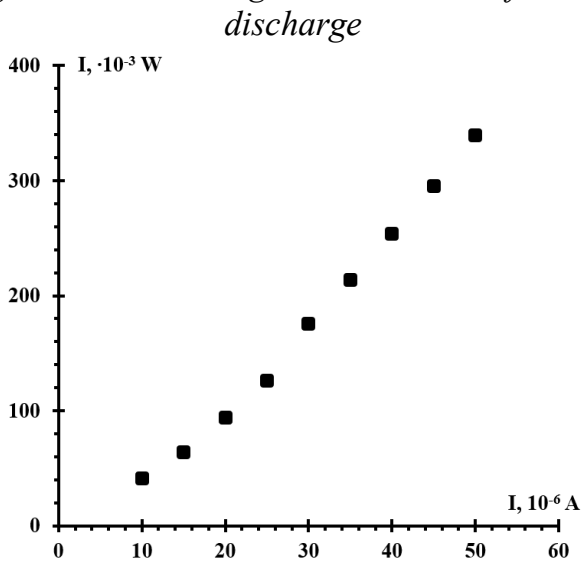

Fig. 3. Dependence of average power of corona discharge on discharge current

Samples 2.1 and 2.2 feature a small number of colonies created on a periphery of the Petri dish, which indicates the insufficient radius of the corona discharge influence on the studied samples. In comparison to the control sample, this operating mode was destructive for bacteria. Comparison between the samples 3.1, 3.2, and control has shown that this operating mode of the corona discharge was insufficient for the inactivation of the bacteria. The operating mode used for samples 4.1 and 4.2 did not inhibit the growth of bacteria and was not enough to cause the inactivation, as for all cases the quantity of colonies was comparable with the control sample. 
For the second stage, we selected the optimal modes from the previous experiments. The Pseudomonas syringae was added for the comparison of results. The treatment modes of Serratia marcescens and Pseudomonas syringae bacteria are shown in Tables 2 and 3 respectively.

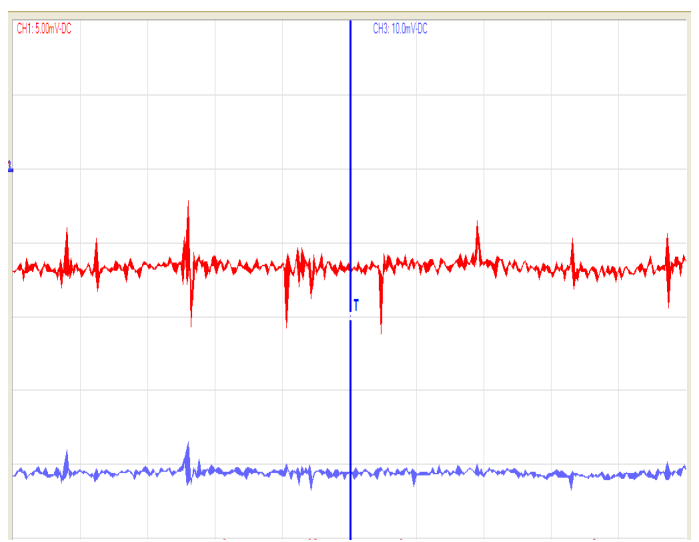

Fig. 4. Typical current (blue) and voltage (red) oscillograms of corona discharge in air: voltmeter-measured voltage $U=6 \mathrm{kV}$; ammeter-measured current $I=40 \mu$ A; horizontal section - $10 \mu \mathrm{s} /$ div; voltage multiplier - $1 \mathrm{kV} / \mathrm{mV}$; current multiplier $-1 \mu \mathrm{A} / \mathrm{mV}$

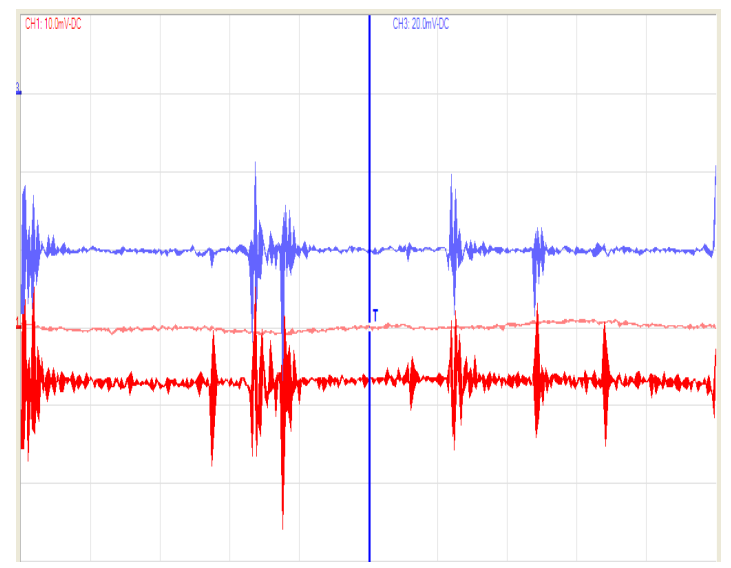

Fig. 5. Typical current (blue) and voltage (red) oscillograms of corona discharge at $5 \mathrm{~mm}$ from water surface: voltmeter-measured voltage $U=7 \mathrm{kV}$; ammeter-measured current $I=40 \mu A$; horizontal section - $5 \mu \mathrm{s} /$ div; voltage multiplier $-1 \mathrm{kV} / \mathrm{mV}$; current multiplier $-1 \mu \mathrm{A} / \mathrm{mV}$

Table 1

Modes of treatment for Serratia marcescens bacteria

\begin{tabular}{|c|c|c|c|c|}
\hline № & $\mathrm{I}, \mu \mathrm{A}$ & $\mathrm{U}, \mathrm{kV}$ & $\mathrm{t}, \mathrm{min}$ & $\mathrm{P}, \mathrm{W}$ \\
\hline 2.1 & 40 & 7.7 & 10.0 & 0.30 \\
\hline 2.2 & 40 & 7.7 & 10.0 & 0.30 \\
\hline 3.1 & 40 & 7.9 & 5.0 & 0.31 \\
\hline 3.2 & 40 & 7.7 & 5.0 & 0.30 \\
\hline 4.1 & 40 & 7.6 & 2.5 & 0.30 \\
\hline 4.2 & 40 & 7.7 & 2.5 & 0.30 \\
\hline
\end{tabular}

Table 2

Modes of treatment for Serratia marcescens bacteria

\begin{tabular}{|c|c|c|c|c|}
\hline № & $\mathrm{I}, \mu \mathrm{A}$ & $\mathrm{U}, \mathrm{kV}$ & $\mathrm{t}, \mathrm{min}$ & $\mathrm{P}, \mathrm{W}$ \\
\hline 1.1 & 40 & 7.5 & 10 & 0.3 \\
\hline 1.2 & 40 & 7.7 & 15 & 0,3 \\
\hline 1.3 & 40 & 7.5 & 20 & 0.3 \\
\hline
\end{tabular}
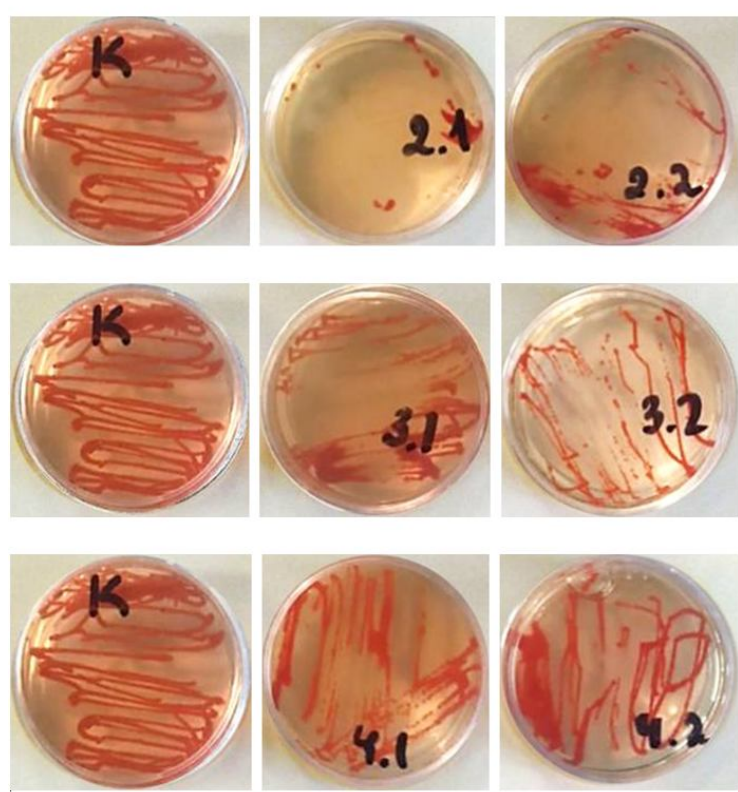

Fig. 6. Photo of control sample of treated Serratia marcescens: 2.1, 2.2 - colony after 10 min plasma treatment; 3.1, 3.2 - colony after 5 min plasma treatment; 4.1, 4.2 - colony after 2.5 min plasma treatment

Table 3

Modes of treatment for Pseudomonas syringae bacteria

\begin{tabular}{|c|c|c|c|c|}
\hline № & $\mathrm{I}, \mu \mathrm{A}$ & $\mathrm{U}, \mathrm{kV}$ & $\mathrm{t}, \mathrm{min}$ & $\mathrm{P}, \mathrm{W}$ \\
\hline 2.1 & 40 & 7.5 & 5 & 0.3 \\
\hline 2.2 & 40 & 7.7 & 5 & 0.3 \\
\hline 3.1 & 40 & 7.5 & 7.5 & 0.3 \\
\hline 3.2 & 39 & 7.6 & 7.5 & 0.29 \\
\hline 4.1 & 37 & 7.8 & 15 & 0.28 \\
\hline 5.1 & 39 & 7.6 & 10 & 0.29 \\
\hline 5.2 & 37 & 7.7 & 10 & 0.28 \\
\hline 6.1 & 45 & 7.3 & 7.5 & 0.32 \\
\hline 6.2 & 45 & 7.3 & 7.5 & 0.32 \\
\hline 6.3 & 45 & 7.5 & 7.5 & 0.33 \\
\hline
\end{tabular}

Fig. 7 shows the general view of the Serratia marcescens colonies on the third day of incubation. Control K1 features an intensive growth of the bacterial culture, the colonies are not separated and blend together. Sample 1.3 features the formation of the separate negative colonies, which indicates a significantly lower quantity of bacterial cells in samples and can be explained by the influence of the physical factor on the cell survival in these conditions. As such, the corona discharge treatment of Serratia marcescens bacteria led to the decrease of the number of surviving cells. The treatment had a rather interesting impact on the pigment production by the bacterial cells. Photo of sample 1.3 on Fig. 8 features an appearance of a metallic shine that is absent in a control sample, which can indicate that corona discharge influenced the expression of some of the genes responsible for pigment production.

The influence of corona discharge on the Pseudomonas syringae bacteria was investigated. The photos of control samples of Pseudomonas syringae bacteria and samples treated by the corona discharge are shown in 
Fig. 9. Treatment modes 2 and 5 inhibit the culture growth, however, some cases showed growth on the periphery of the Petri dish, which indicates the insufficient radius of the growth medium treatment. Selected treatment modes at $0.3 \mathrm{~W}$ discharge power and $7.5 \mathrm{~min}$ treatment time were destructive, which led to the destruction of colonies in samples 3.1 and 3.2 when compared to the control. Sample 4.1 shows the complete inhibition of the bacterial culture growth in comparison to the control sample (see Fig. 9).

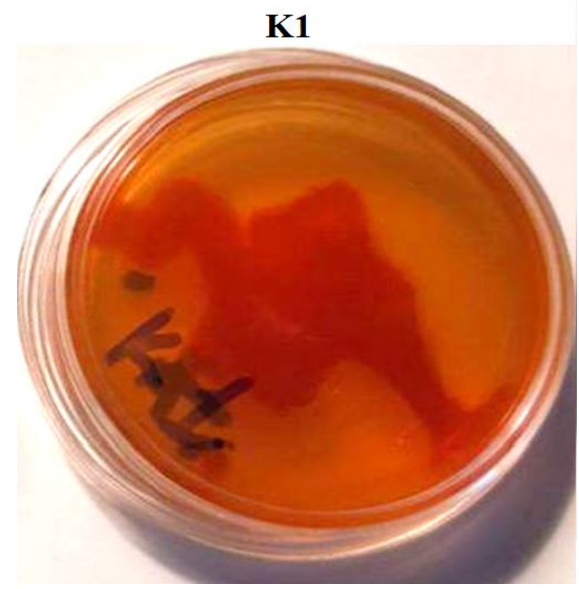

1.3

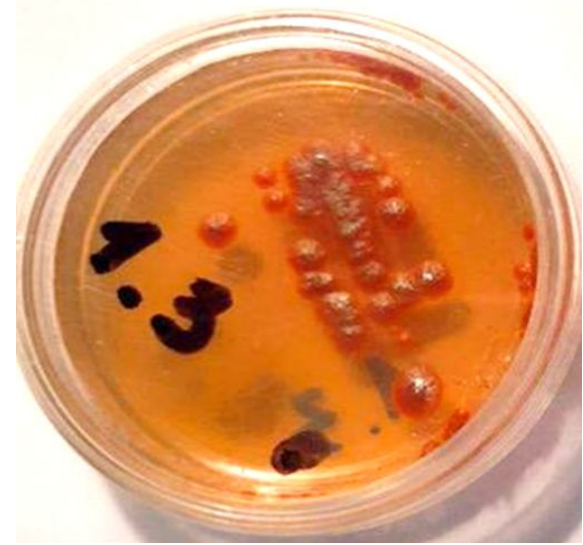

Fig. 7. General view of Serratia marcescens colony on $3^{\text {rd }}$ day of incubation on LB agar medium: K1 - control; 1.3 - after 20 min of corona discharge treatment using

1.3 treatment mode with $0.3 \mathrm{~W}$ discharge power

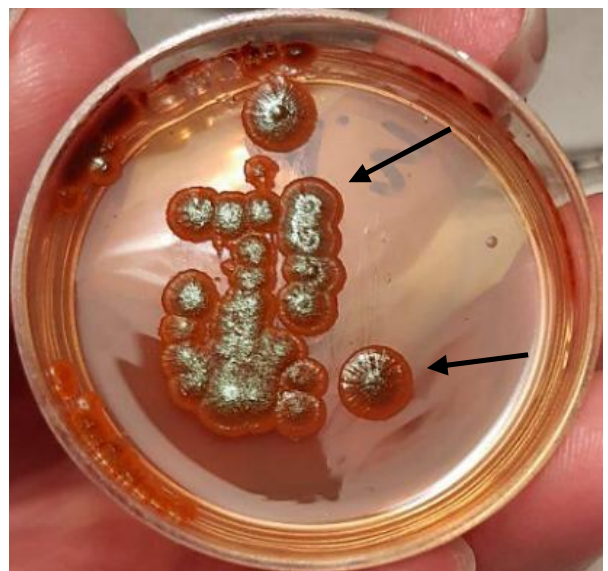

Fig. 8. Specific coloring of Serratia marcescens colonies on $5^{\text {th }}$ day of incubation after $20 \mathrm{~min}$

of corona discharge treatment using 1.3 treatment mode with $0.3 \mathrm{~W}$ discharge power
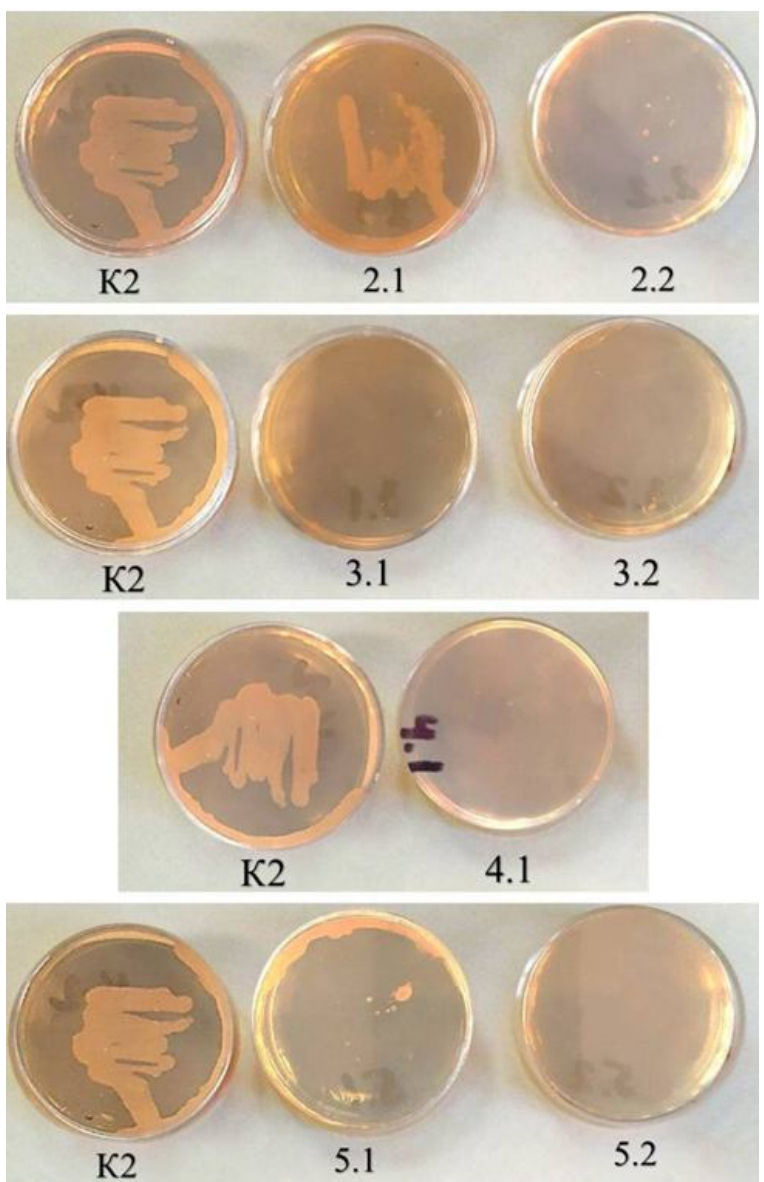

Fig. 9. Comparison between control and treated

samples of Pseudomonas syringae bacteria: $a-5$ min treatment time; $b-7.5$ mins treatment time; $c-15$ min treatment time; $d-10$ min treatment time

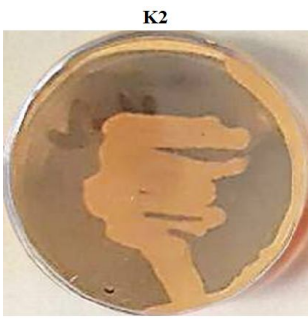

6.2

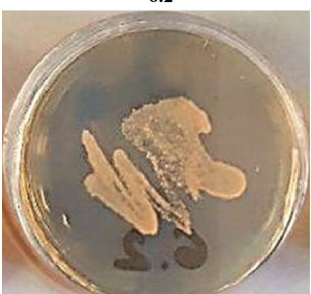

Fig. 10. Influence of 7.5 min treatment by corona discharge on growth of Pseudomonas syringae

Fig. 10 shows the bacterial treatment mode 6. Sample 6.1 was under a cover and the pin was raised $10 \mathrm{~mm}$ over the sample. Sample 6.2 was without a cover and the pin was similarly raised to $10 \mathrm{~mm}$ over the sample. Sample 6.3 was without a cover and the pin was at the level of the Petri dish. Comparison between all samples shows that corona discharge had a bigger effect on sample 6.3 when compared with the control. It did not, however, completely inhibit the growth of bacteria if compared with the previous modes. 
Fig. 11 shows the absorption coefficient of the treated distilled water at the different light wavelengths. Distilled water was treated at a $7 \mathrm{kV}$ discharge voltage and a $40 \mu \mathrm{A}$ discharge current. The distance from the pin to the surface of the liquid was $5 \mathrm{~mm}$.

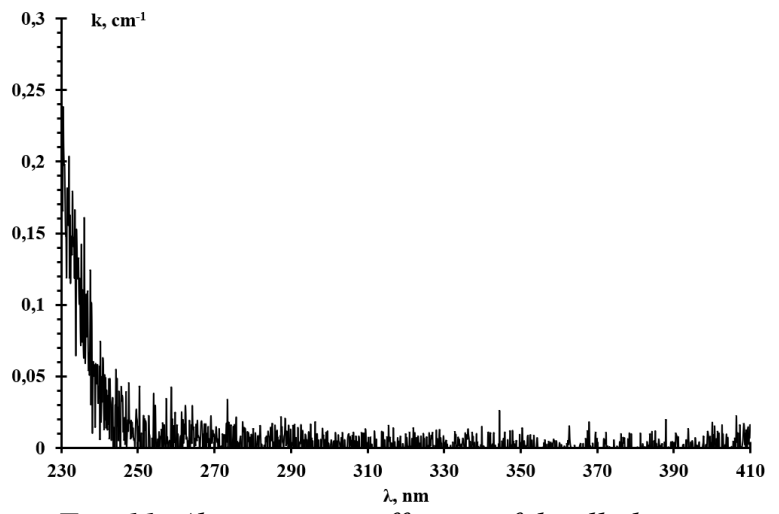

Fig. 11. Absorption coefficient of distilled water at different light wavelength after 20 min treatment

Obtained absorption coefficient dependency on the wavelength hints at the presence of hydrogen peroxide in the spectrum between 230 and $250 \mathrm{~nm}$ wavelength. The production of a small amount of hydrogen peroxide is caused by the low power of the corona discharge.

\section{CONCLUSIONS}

Several treatment modes were discovered, which will allow using $0.3 \mathrm{~W}$ corona discharge to destroy Serratia marcescens and Pseudomonas syringae bacteria in the treated area or decrease their quantity by several orders of magnitude.

The minimal treatment time required for the destruction of Pseudomonas syringae bacteria using $0.3 \mathrm{~W}$ corona discharge is $7.5 \mathrm{~min}$.

A 20-min treatment of Serratia marcescens bacteria by the corona discharge leads to the appearance of the metallic shine, which is absent from the control sample. This probably indicates that corona discharge influences the expression of some of the genes responsible for pigment production in the bacteria.

\section{ACKNOWLEDGEMENTS}

This work was supported in part by the Ministry of Education and Science of Ukraine, the National Academy of Sciences of Ukraine, and the Taras Shevchenko National University of Kyiv.

\section{REFERENCES}

1. B.B. Baldanov, T.V. Ranzhurov, A.P. Semenov and SV. Gomboeva. Cold atmospheric argon plasma jet source and its application for bacterial inactivation // Journal of Theoretical and Applied Physics. 2019, v. 13 , p. 95-99.

2. A.R. Galaly and H.H. Zahran. Inactivation of Bacteria using Combined Effects of Magnetic Field, Low Pressure and Ultra Low Frequency Plasma Discharges (ULFP) // Journal of Physics: Conference Series. 2013, v. 431, p. 012014. (8 p.).

3. N. Puač, M. Miletić, M. Mojović, A. Popović-Bijelić, et al. Sterilization of bacteria suspensions and identification of radicals deposited during plasma treatment // Open Chem. 2015, v. 13, p. 332-338.

4. N. Hojnik, M. Modic, Y. Ni, G. Filipic, U. Cvelbar and J. Walsh. Effective Fungal Spore Inactivation with an Environmentally Friendly Approach Based on Atmospheric Pressure Air Plasma // Environ. Sci. Technol. 2019, v. 53, № 4, p. 1893-1904.

5. R. Morent and N. De Geyter. Inactivation of Bacteria by Non-Thermal Plasmas Research Unit Plasma Technology. 2010, p. 42.

6. O.A. Nedybaliuk, Yu.P. Veremii, N.V. Tsvyd, et al. Impact of corona discharge on Aspergilius niger spores and Cyathus olla mycelium growth // Problems of Atomic Science and Technology. 2020, № 6, p. 185-189.

7. I.I. Fedirchyk, O.A. Nedybaliuk, L.Yu. Vergun, et al. Influence of plasma on surface tension of hydrocarbons // Problems of Atomic Science and Technology. 2015, № 1, p. 239-242.

8. O.A. Nedybaliuk, I.I. Fedirchyk, V.Ya. Chernyak. Influence of corona discharge on paraffin combustion // Problems of Atomic Science and Technology. 2018, № 6, p. 218-221.

Article received 02.06.2021

\section{ВЛИЯНИЕ КОРОННОГО РАЗРЯДА НА ИНАКТИВАЦИЮ SERRATIA MARCESCENS И PSEUDOMONAS SYRINGAE О.А. Недыбалюк, Н.С. Кот, А.В. Харина, И.И. Федирчик}

Исследовано влияние коронного разряда на бактериальные культуры Serratia marcescens и Pseudomonas syringae при различных режимах работы. Измерены вольт-амперные характеристики коронного разряда в диапазоне токов 4..50 мкА. Измерены типичные осциллограммы тока и напряжения коронного разряда в воздухе и когда острие было расположено вблизи поверхности жидкости. Определены режимы работы, при которых с помощью обработки коронным разрядом мощностью 0,3 Вт удается уменьшить количество бактерий Serratia marcescens и Pseudomonas syringae на несколько порядков или полностью их уничтожить. Измерены спектры поглощения обработанной коронным разрядом дистиллированной воды.

\section{ВПЛИВ КОРОННОГО РОЗРЯДУ НА ІНАКТИВАЦІЮ SERRATIA MARCESCENS TA PSEUDOMONAS SYRINGAE \\ О.А. Недибалюк, Н.С. Кот, А.В. Харіна, I.I. Федірчик}

Досліджено вплив коронного розряду на бактеріальні культури Serratia marcescens та Pseudomonas syringae за різних режимів роботи. Виміряно вольт-амперні характеристики коронного розряду в діапазоні струмів 4...50 мкА. Виміряно типові осцилограми струму та напруги коронного розряду в повітрі та коли вістря було розташоване поблизу поверхні рідини. Виявлено режими роботи, при яких за допомогою обробки коронним розрядом потужністю 0,3 Вт вдається зменшити кількість бактерій Serratia marcescens та Pseudomonas syringae на декілька порядків або повністю їх знищити. Виміряно спектри поглинання обробленої коронним розрядом дистильованої води. 